\title{
Synthesis of indium oxi-sulfide films by atomic layer deposition: The essential role of plasma enhancement
}

\author{
Cathy Bugot ${ }^{\star}$, Nathanaëlle Schneider, Daniel Lincot
} and Frédérique Donsanti ${ }^{*}$

\section{Full Research Paper}

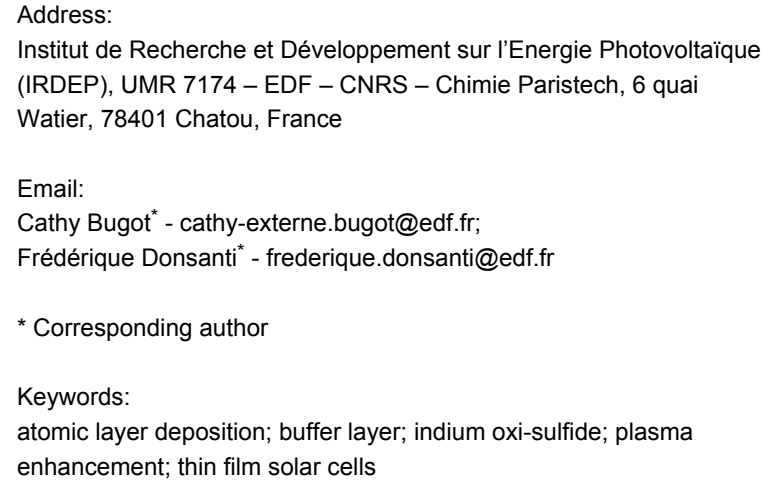

\begin{abstract}
This paper describes the atomic layer deposition of $\operatorname{In}_{2}(\mathrm{~S}, \mathrm{O})_{3}$ films by using $\operatorname{In}(\mathrm{acac})_{3}$ (acac = acetylacetonate), $\mathrm{H}_{2} \mathrm{~S}$ and either $\mathrm{H}_{2} \mathrm{O}$ or $\mathrm{O}_{2}$ plasma as oxygen sources. First, the growth of pure $\mathrm{In}_{2} \mathrm{~S}_{3}$ films was studied in order to better understand the influence of the oxygen pulses. X-Ray diffraction measurements, optical analysis and energy dispersive X-ray spectroscopy were performed to characterize the samples. When $\mathrm{H}_{2} \mathrm{O}$ was used as the oxygen source, the films have structural and optical properties, and the atomic composition of pure $\mathrm{In}_{2} \mathrm{~S}_{3}$. No pure $\mathrm{In}_{2} \mathrm{O}_{3}$ films could be grown by using $\mathrm{H}_{2} \mathrm{O}$ or $\mathrm{O}_{2}$ plasma. However, $\mathrm{In}_{2}(\mathrm{~S}, \mathrm{O})_{3}$ films could be successfully grown by using $\mathrm{O}_{2}$ plasma as oxygen source at a deposition temperature of $T=160{ }^{\circ} \mathrm{C}$, because of an exchange reaction between $\mathrm{S}$ and $\mathrm{O}$ atoms. By adjusting the number of $\mathrm{In}_{2} \mathrm{O}_{3}$ growth cycles in relation to the number of $\mathrm{In}_{2} \mathrm{~S}_{3}$ growth cycles, the optical band gap of the resulting thin films could be tuned.
\end{abstract}

\section{Introduction}

Chalcopyrite-type thin film solar cells that are based on a $\mathrm{Cu}(\mathrm{In}, \mathrm{Ga}) \mathrm{Se}_{2}$ (CIGS) absorber have reached high efficiencies, up to $20.3 \%$ [1] in 2011 and $20.4 \%$ [2] on flexible substrates in 2013. The best efficiencies were obtained by using cadmium sulfide $(\mathrm{CdS})$ as buffer layer in solar cells with a glass/Mo/ CIGS/CdS/i-ZnO/ZnO:Al stack. The buffer layer is an n-type semiconductor that forms the $\mathrm{p}-\mathrm{n}$ junction with the $\mathrm{p}$-type CIGS absorber, and also modifies the CIGS surface chemistry, which is usually too sensitive for a direct deposition of the window layers. However, because of the toxicity of cadmium and the low optical band gap of $\mathrm{CdS}(2.4 \mathrm{eV}$ [3]) that limits the light conversion of CIGS in the UV range of the solar spectrum, 
alternative materials have been developed. Most Cd-free buffer layers are based on zinc and indium-compounds, with current record efficiencies obtained by chemical bath deposition (CBD, $19.7 \%$ and $19.1 \%$ for $\mathrm{Zn}(\mathrm{S}, \mathrm{O}, \mathrm{OH})[4,5], 15.7 \%$ for $\operatorname{In}(\mathrm{S}, \mathrm{O}, \mathrm{OH})$ [6]) or atomic layer deposition (ALD, $18.5 \%$ for $\mathrm{Zn}(\mathrm{O}, \mathrm{S})$ [7], $18.1 \%$ for $(\mathrm{Zn}, \mathrm{Mg}) \mathrm{O}$ [8], $16.4 \%$ for $\mathrm{In}_{2} \mathrm{~S}_{3}$ [9], and $18.2 \%$ for $(\mathrm{Zn}, \mathrm{Sn}) \mathrm{O}[10])$. Recently, our group has synthesized new mixed films of $\mathrm{ZnS} / \mathrm{In}_{2} \mathrm{~S}_{3}$ by using ALD and applied them as buffer layers in CIGS solar cells $[11,12]$. ALD is based on sequential self-saturated reactions that allows the conformal and uniform growth of thin films with a high control of their properties [1315]. It is therefore a suitable technique for the deposition of buffer layers. Platzer-Björkman et al. have used ALD to improve the energy-band alignment between the CIGS and the front electrode by controlling the oxygen concentration in $\mathrm{Zn}(\mathrm{S}, \mathrm{O})$ buffer layers $[4,16]$. Oxygen-doping of $\operatorname{In}_{2} \mathrm{~S}_{3}$ films is known to increase their optical band gap value $[6,17,18]$. Indeed, by O-doping of $\operatorname{In}_{2} \mathrm{~S}_{3}$ films deposited by thermal evaporation, Barreau et al. could increase the optical band gap value of $\mathrm{In}_{2} \mathrm{~S}_{3}$ thin films from 2.1 to $2.9 \mathrm{eV}$ [17]. In the same way, by using the spray pyrolysis technique, Maha et al. have inserted sulfur atoms in $\mathrm{In}_{2} \mathrm{O}_{3}$ thin films and obtained optical band gaps in the range from 3.85 to $3.96 \mathrm{eV}$ [18]. Thus, based on our previous results and those studies, we became interested in adjusting the optical properties of $\operatorname{In}_{2} \mathrm{~S}_{3}$ by incorporating oxygen atoms while using the advantages of ALD. Typical ALD processes for the deposition of $\mathrm{In}_{2} \mathrm{~S}_{3}$ and $\mathrm{In}_{2} \mathrm{O}_{3}$ are referenced in Table 1. As ALD processes of $\mathrm{In}_{2} \mathrm{O}_{3}$ report relatively small growth rates, we will consider the case of plasma enhancement. Indeed, plasma-enhanced ALD (PEALD), in which various reactive species are generated, has been the key for the development of fast thin-film deposition processes at low temperature. It is widely used to enhance the thin-film deposition of materials such as $\mathrm{Al}_{2} \mathrm{O}_{3}, \mathrm{ZnO}, \mathrm{Ta}_{2} \mathrm{O}_{5}, \mathrm{TiN}, \mathrm{TaN}$ and $\operatorname{SiN}_{x}[19]$.
In this study, ALD and PEALD have been used to synthesize $\mathrm{In}_{2}(\mathrm{~S}, \mathrm{O})_{3}$ thin films and carry out optical band-gap engineering. The structural, optical and growth properties of the films will be studied and the role of the plasma will be discussed.

\section{Results \\ Study of $\operatorname{In}(\mathrm{acac})_{3}, \mathrm{H}_{2} \mathrm{~S}$ and $\mathrm{H}_{2} \mathrm{O}$ system}

First, a controlled growth of pure $\mathrm{In}_{2} \mathrm{~S}_{3}$ films was established and the film properties were measured in order to clearly identify the influence of oxygen pulse later in the study. For that, $\mathrm{In}_{2} \mathrm{~S}_{3}$ growth was achieved in the temperature range between 140 and $240{ }^{\circ} \mathrm{C}$. An $\mathrm{In}_{2} \mathrm{~S}_{3}$ growth cycle consists of the following steps: $\mathrm{In}(\mathrm{acac})_{3}$ exposure $/ \mathrm{N}_{2}$ purge $/ \mathrm{H}_{2} \mathrm{~S}$ exposure $/ \mathrm{N}_{2}$ purge $=0.1 / 5 / 0.1 / 5 \mathrm{~s}$, the relative long purge time being chosen to ensure a good homogeneity. Figure 1a shows the growth rate of $\mathrm{In}_{2} \mathrm{~S}_{3}$ thin films at various temperatures. It globally increases with the temperature. An ALD window can be speculatively observed between $160{ }^{\circ} \mathrm{C}$ and $200{ }^{\circ} \mathrm{C}$ with a mean growth rate of $0.84 \AA$ /cycle. The variation of the $\operatorname{In}_{2} \mathrm{~S}_{3}$ growth rate with different $\operatorname{In}(\mathrm{acac})_{3}$ pulse lengths at a process temperature of $160{ }^{\circ} \mathrm{C}$ is illustrated in Figure $1 \mathrm{~b}$. This variation only slightly influences the growth rate and a saturation by lengthening the precursor pulse is not observed. The data suggest that the results displayed on Figure 1a may not have been obtained under completely self-limiting conditions. Structural and optical properties of the films were also investigated. $\operatorname{In}_{2} \mathrm{~S}_{3}$ thin films have an amorphous structure for deposition temperatures below $180{ }^{\circ} \mathrm{C}$ and a $\beta$-tetragonal crystal structure at higher temperatures. Their indirect optical band gap varies from $2.0 \mathrm{eV}$ to $2.2 \mathrm{eV}$.

Then, we attempted to synthesize $\operatorname{In}_{2}(\mathrm{~S}, \mathrm{O})_{3}$ film by inserting an $\mathrm{In}_{2} \mathrm{O}_{3}$ growth cycle. For this $\mathrm{H}_{2} \mathrm{O}$ was pulsed, instead of $\mathrm{H}_{2} \mathrm{~S}$ in the growth of pure $\operatorname{In}_{2} \mathrm{~S}_{3}$, which led to the supercycles $n \cdot\left\{\operatorname{In}_{2} \mathrm{~S}_{3}\right\}+\left\{\operatorname{In}_{2} \mathrm{O}_{3}\right\}$ with $n=1,2,3,5,9,14,19$, which corres-

\begin{tabular}{|c|c|c|c|c|}
\hline reactant $A$ & reactant B & temperature $\left({ }^{\circ} \mathrm{C}\right)$ & growth rate $(\AA /$ cycle $)$ & reference \\
\hline \multicolumn{5}{|c|}{ indium oxide } \\
\hline $\operatorname{lnCl}_{3}$ & $\mathrm{H}_{2} \mathrm{O}$ & 500 & 0.27 & {$[20]$} \\
\hline $\operatorname{lnCp}$ & $\mathrm{O}_{3} / \mathrm{O}_{2} / \mathrm{H}_{2} \mathrm{O}$ & 250 & $1.3 / 0.16 / 0.068$ & [21] \\
\hline $\operatorname{InCp}$ & $\mathrm{H}_{2} \mathrm{O} \& \mathrm{O}_{2}$ & $100-250$ & $1.0-1.6$ & {$[22]$} \\
\hline Tmln & $\mathrm{H}_{2} \mathrm{O}$ & 217 & 0.39 & {$[23]$} \\
\hline $\ln (\mathrm{acac})_{3}$ & $\mathrm{H}_{2} \mathrm{O} / \mathrm{O}_{3}$ & $165-225$ & $0.2 / 0.12$ & {$[24]$} \\
\hline \multicolumn{5}{|c|}{ indium sulfide } \\
\hline $\mathrm{InCl}_{3}$ & $\mathrm{H}_{2} \mathrm{~S}$ & 300 & 1.4 & [25] \\
\hline $\ln (\operatorname{acac})_{3}$ & $\mathrm{H}_{2} \mathrm{~S}$ & $160,180,160,150$ & $0.6,0.7,0.44,0.3$ & {$[9,26-28]$} \\
\hline
\end{tabular}



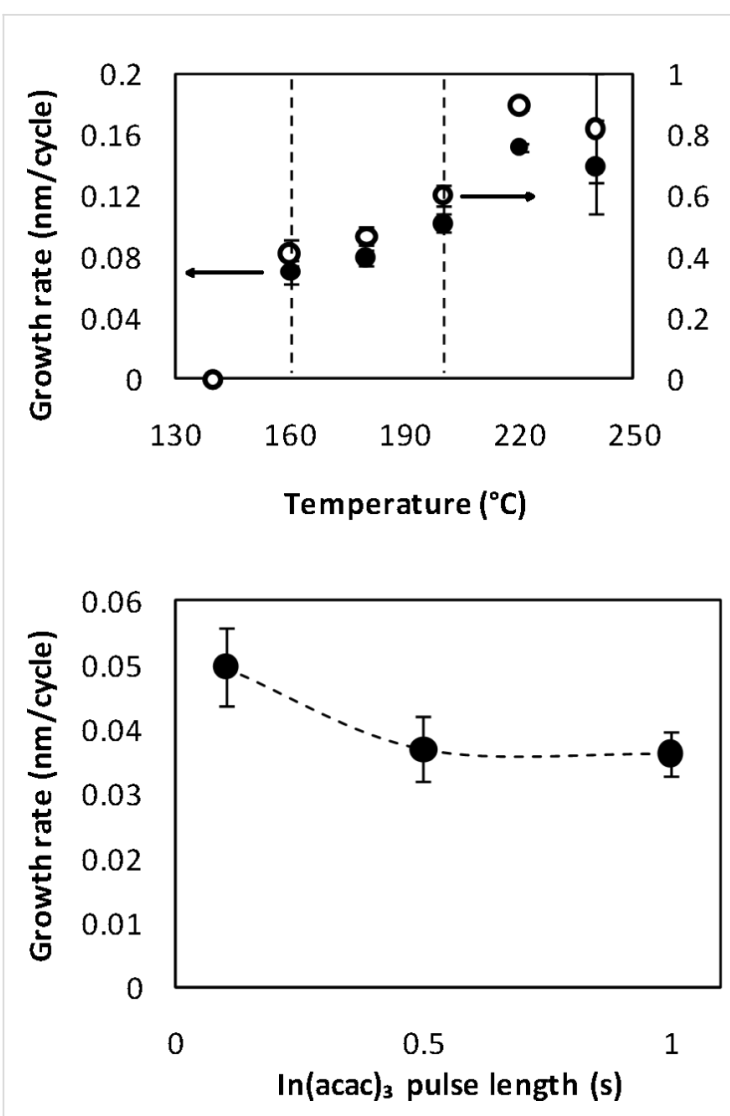

Figure 1: Growth rate of pure $\ln _{2} S_{3}$ a) as function of the process temperature $b$ ) as function of the $\ln (\mathrm{acac})_{3}$ pulse length.

pond to ratios of $\{50 \%, 33 \%, 25 \%, 10 \%, 6.7 \%, 5 \%\}$ of $\operatorname{In}_{2} \mathrm{O}_{3}$ cycles at a deposition temperature of $200{ }^{\circ} \mathrm{C}$. All samples were deposited performing a total of 2000 growth cycles, i.e., 100 supercycles for $n=19,133$ supercycles for $n=14$, etc. Energy dispersive X-ray spectroscopy analysis was performed on the samples and gave atomic ratios of 0.4 for $\mathrm{In} /(\mathrm{In}+\mathrm{S})$ and 0.6 for $\mathrm{S} /(\mathrm{In}+\mathrm{S})$, which correspond to typical $\mathrm{In}_{2} \mathrm{~S}_{3}$ atomic ratios. The oxygen contents are similar to those of pure $\operatorname{In}_{2} \mathrm{~S}_{3}$ films, which is assigned to the oxygen contamination of the substrate. Those results were confirmed by GI-XRD measurements. They were performed to investigate the influence of the $\mathrm{H}_{2} \mathrm{O}$ pulse on the microstructure of the films (Figure 2b). Not all samples were crystalline and the crystalline ones can be attributed to $\beta-\mathrm{In}_{2} \mathrm{~S}_{3}$ with a random orientation by comparing the diffraction patterns with the reference data and with the literature [27]. Indeed, we should observe a peak shift due to increasing oxygen doping when changing the $\mathrm{In}_{2} \mathrm{O}_{3} / \mathrm{In}_{2} \mathrm{~S}_{3}$ ratio. However, the peaks remain at the same diffraction angles. Comparing the FWHM of the (109) peak, the maximum FWHM measured was $1.2^{\circ}$ for the $10 \%-\mathrm{In}_{2} \mathrm{O}_{3}$ sample, which corresponds to the thickest film. In general it can be said that the thinner the films, the lower the FWHM. From these observations, it seems that we obtained $\mathrm{In}_{2} \mathrm{~S}_{3}$ films only.

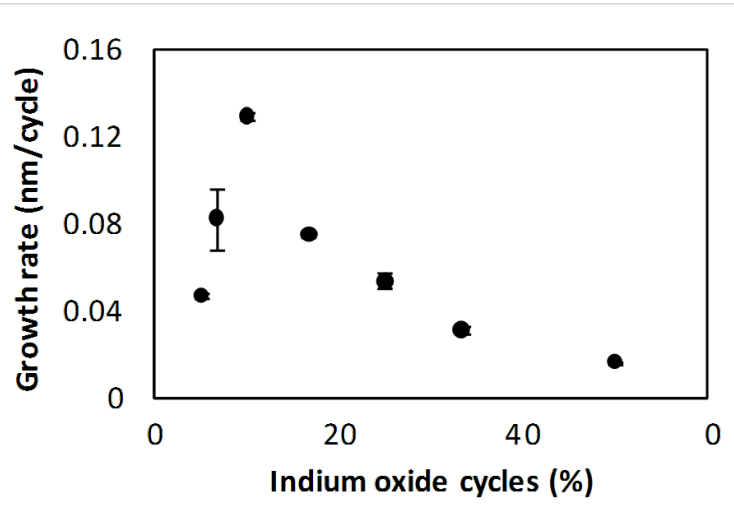

a

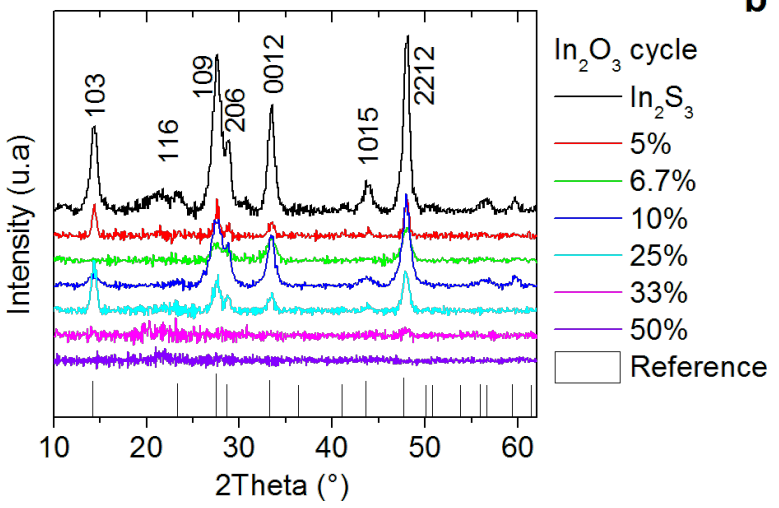

Figure 2: Influence of the number of $\ln _{2} \mathrm{O}_{3}$ cycles on (a) the growth rate while using $\mathrm{H}_{2} \mathrm{O}$ as oxygen precursor and (b) GIXRD diffractogram. The reference diffraction pattern for $\ln _{2} S_{3}$ is taken from the database JCPDS 00-005-0731.

Thin films optical absorption were determined from transmittance $(T)$ and reflectance $(R)$ measurements by using the following formula [29]

$$
\alpha=-\frac{1}{t} \cdot \ln \left(\frac{(1-T)}{R}\right),
$$

where $\alpha$ is the absorption coefficient and $t$ is the film thickness. Figure 3 shows absorption spectra of the thin films. They are presented in the form of $(\alpha)^{0.5}=\mathrm{f}(E)$, which is linear for indirect band gap materials and allows for the determination of the optical transition. The optical band gaps correspond to an indirect transition in the range from 1.9 to $2.2 \mathrm{eV}$, which is roughly similar to that of pure $\operatorname{In}_{2} \mathrm{~S}_{3}$ film optical properties. No correlation could be found between either the ratio of $\operatorname{~}_{2} \mathrm{O}_{3}$ cycles or the film thickness and the optical measurements. These results are in accordance with the observations of the structural analysis. Consequently, this method is not suitable to synthesize $\operatorname{In}_{2}(\mathrm{~S}, \mathrm{O})_{3}$ thin films. In parallel, we attempted to synthesize pure $\mathrm{In}_{2} \mathrm{O}_{3}$ films from $\mathrm{In}(\mathrm{acac})_{3}$ and $\mathrm{H}_{2} \mathrm{O}$ at temperatures of 160 and $200{ }^{\circ} \mathrm{C}$. This remained unsuccessful, because no films could be grown under these conditions. 


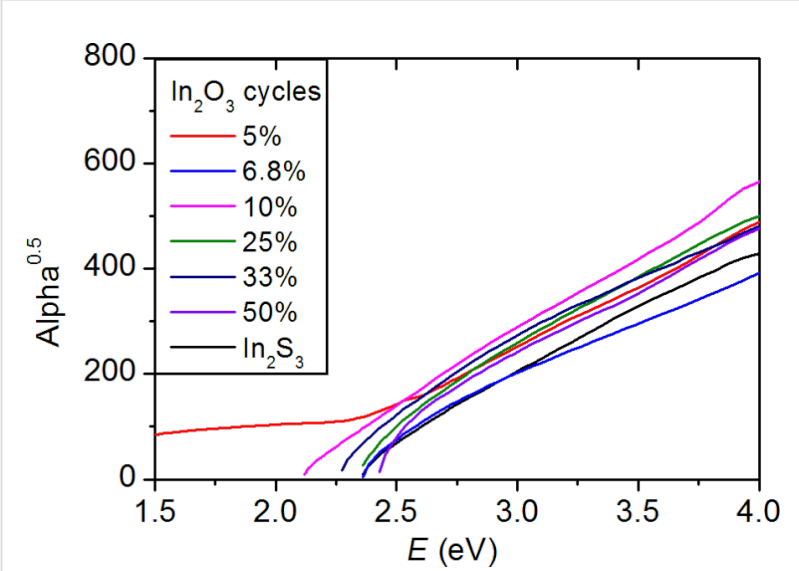

Figure 3: Influence of the ratio of $\ln _{2} \mathrm{O}_{3}$ cycles on the film absorption spectra when using $\mathrm{H}_{2} \mathrm{O}$ as oxygen precursor.

\section{Study of the $\ln (\mathrm{acac})_{3}, \mathrm{H}_{2} \mathrm{~S}$ and $\mathrm{O}_{2}$ plasma system}

As $\mathrm{O}_{2}$ plasma is known to have a different reactivity, it was evaluated as potential oxygen source for the deposition of $\mathrm{In}_{2}(\mathrm{~S}, \mathrm{O})_{3}$. Thin film syntheses were performed by incorporating $\mathrm{In}_{2} \mathrm{O}_{3}$ growth cycles that use $\mathrm{O}_{2}$ plasma pulses in the growth of $\operatorname{In}_{2} \mathrm{~S}_{3}$ : In(acac $)_{3}$ exposure $/ \mathrm{N}_{2}$ purge $/ \mathrm{O}_{2}+$ plasma exposure $/ \mathrm{N}_{2}$ purge $=0.1 / 5 / 7 / 3 \mathrm{~s}$ in the following supercycles $n \cdot\left\{\mathrm{In}_{2} \mathrm{~S}_{3}\right\}+2 \cdot\left\{\mathrm{In}_{2} \mathrm{O}_{3}\right\}$ with $n=15,20,25,30,35,40$ which correspond to ratios of $\{11.8 \%, 9.1 \%, 7.4 \%, 6.25 \%, 5.4 \%$, $4.8 \%$ of $\mathrm{In}_{2} \mathrm{O}_{3}$ cycles at a deposition temperature of $160{ }^{\circ} \mathrm{C}$. A total of 2000 cycles was achieved for all samples as described in the previous section. The dependence of the growth rate on the number of $\mathrm{In}_{2} \mathrm{O}_{3}$ cycles is shown in Figure $4 \mathrm{a}$. When increasing the ratio from $4.8 \%$ to $9.1 \%$, the growth rate increases up to $1.4 \AA$ /cycle and then decreases again. The variation of the film thickness with the number of ALD cycles for a ratio of $10 \%$ of $\operatorname{In}_{2} \mathrm{O}_{3}$ cycles is illustrated in Figure $4 \mathrm{~b}$. A linear growth is observed up to 1500 ALD cycles. GIXRD measurements revealed an amorphous structure in all the samples.

Transmittance and reflectance measurements were carried out on the $\operatorname{In}_{2}(\mathrm{~S}, \mathrm{O})_{3}$ samples. Figure 5 shows the transmittance of $\mathrm{In}_{2}(\mathrm{~S}, \mathrm{O})_{3}$ films as a function of the percentage of $\operatorname{In}_{2} \mathrm{O}_{3}$ cycles. A shift of the onset absorption can be observed, which suggests an evolution in the properties of the films. The indirect optical transitions were identified for all samples from their respective absorption spectra (Figure 6a). The values are plotted as a function of the ratio of $\operatorname{In}_{2} \mathrm{O}_{3}$ cycles in Figure 6b. The maximum value corresponds to the theoretical optical gap of $\mathrm{In}_{2} \mathrm{O}_{3}$ [30] The optical band gaps vary from $2.2 \pm 0.1 \mathrm{eV}$ for pure $\operatorname{In}_{2} \mathrm{~S}_{3}$ to $3.3 \pm 0.1 \mathrm{eV}$ for $\operatorname{In}_{2}(\mathrm{~S}, \mathrm{O})_{3}$ and increase with the number of $\mathrm{In}_{2} \mathrm{O}_{3}$ cycles during the deposition process of $\operatorname{In}_{2} \mathrm{~S}_{3}$.
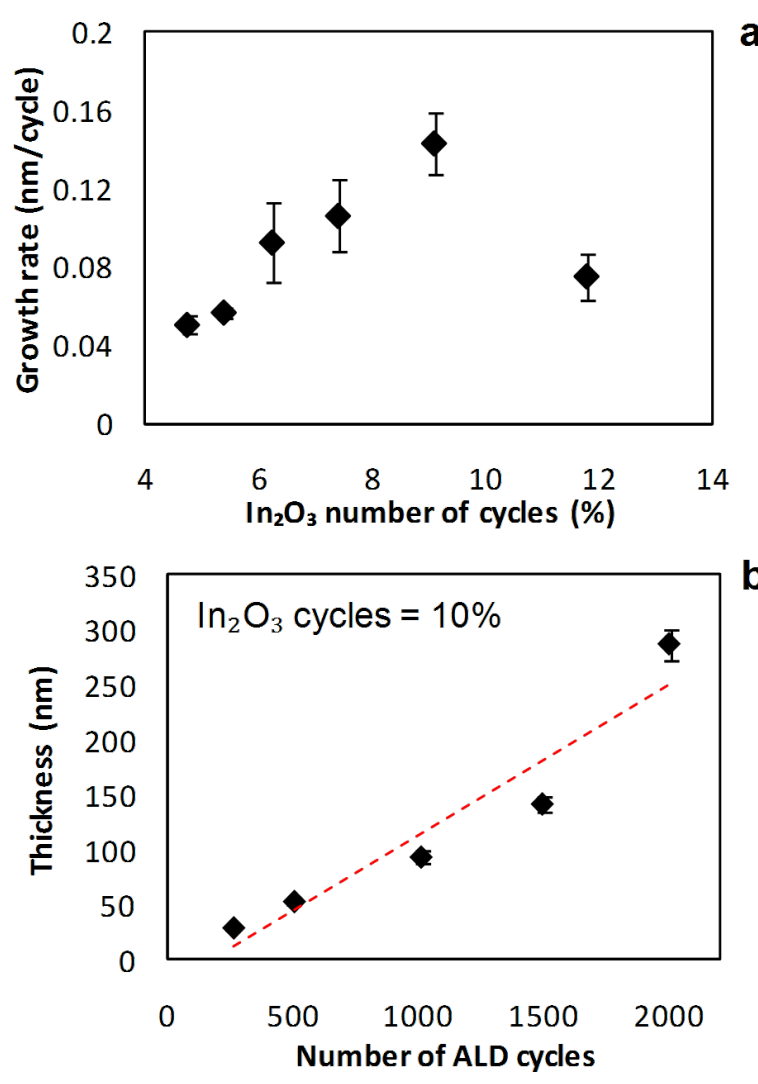

Figure 4: Influence of a) the number of $\ln _{2} \mathrm{O}_{3}$ cycles on the growth rate $b$ ) the number of process cycles on the film thickness when using $\mathrm{O}_{2}$ plasma as oxygen precursor. The dotted line is a guide to the eyes.

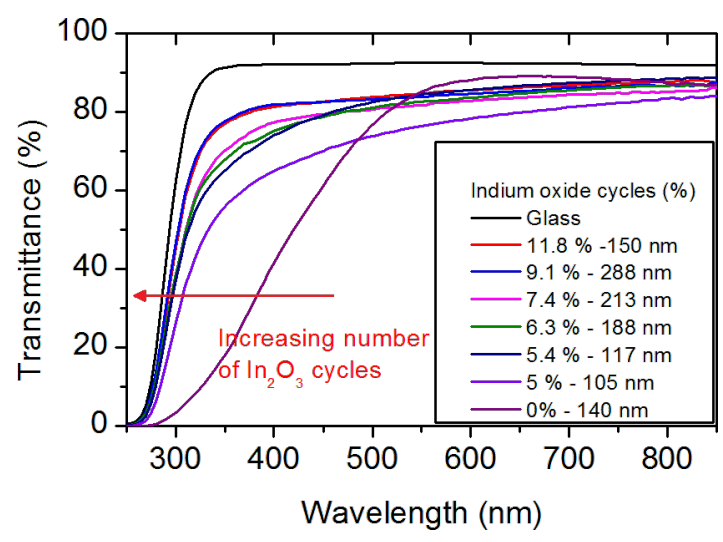

Figure 5: Influence of the number of $\ln _{2} \mathrm{O}_{3}$ cycle on the film transmittance when using $\mathrm{O}_{2}$ plasma as oxygen precursor.

The atomic ratios of oxygen, sulfur and indium determined by using EDX are presented in Table 2 and correlated to the optical band gap values. The dependence of the atomic ratio of oxygen and the optical band gap on the number of $\operatorname{In}_{2} \mathrm{O}_{3}$ cycles is not clear. In general, high oxygen concentrations of more than 66 atom $\%$ were measured in the films. 

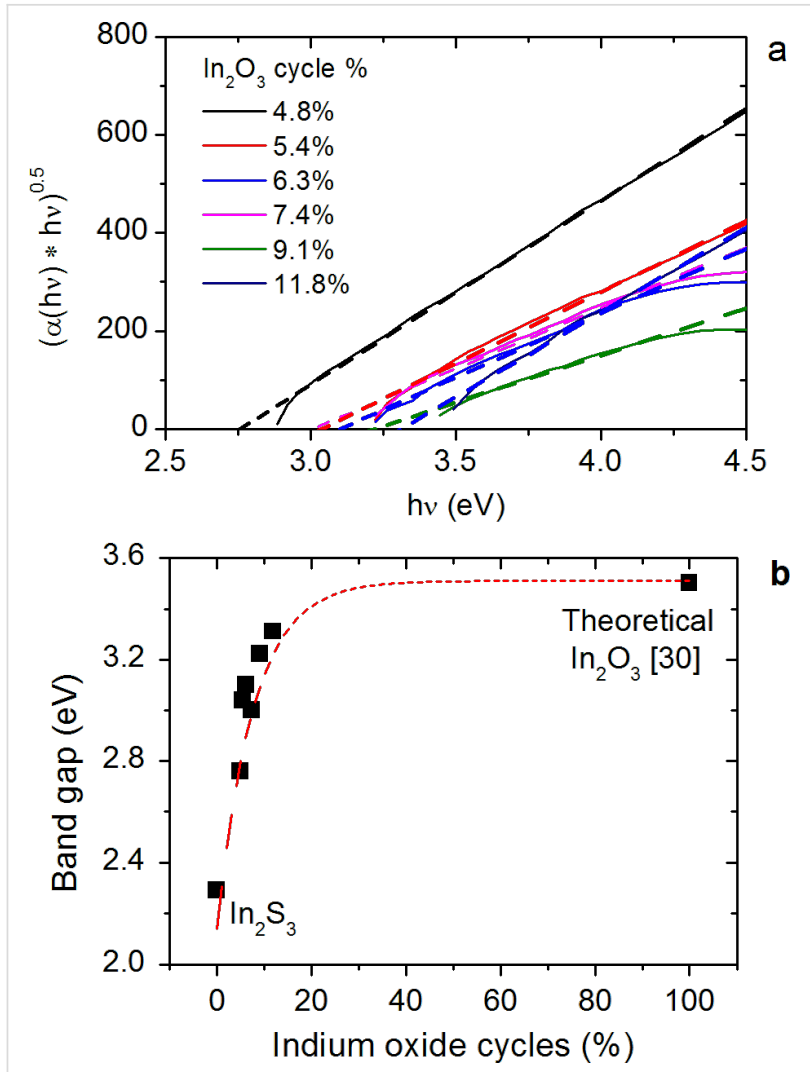

Figure 6: Influence of the number of $\ln _{2} \mathrm{O}_{3}$ cycles a) on the absorption and b) optical band gap when using $\mathrm{O}_{2}$ plasma as oxygen precursor. The dotted line is a guide to the eyes.

We also tried to synthesize $\operatorname{In}_{2}(\mathrm{~S}, \mathrm{O})_{3}$ by using a single $\mathrm{O}_{2}$ plasma pulse instead of $\operatorname{In}_{2} \mathrm{O}_{3}$ pulse cycles. The following cycle program was used: $20 \cdot\left\{\mathrm{In}_{2} \mathrm{~S}_{3}\right\}+2 \cdot\left\{\mathrm{O}_{2}+\right.$ plasma exposure $\} / \mathrm{N}_{2}$ purge with the same process parameters. This corresponds to $9.1 \%$ of indium cycles, which can be compared to the previous deposition with a pulse of $\operatorname{In}(\mathrm{acac})_{3}$ before the $\mathrm{O}_{2}$ plasma exposure. Table 3 shows the properties of these two samples, along with those of pure $\mathrm{In}_{2} \mathrm{~S}_{3}$. Even without the $\mathrm{In}(\mathrm{acac})_{3}$ pulse, $\mathrm{O}$ and $\mathrm{S}$ atomic ratios indicate that the synthesized film corresponds to a $\operatorname{In}_{2}(\mathrm{~S}, \mathrm{O})_{3}$ film and no significant differences were observed between the samples.

The growth of $\operatorname{In}_{2}(\mathrm{~S}, \mathrm{O})_{3}$ growth could be achieved when using $\mathrm{O}_{2}$ plasma as oxygen precursor. The maximum growth rate was $1.4 \AA$ /cycle, which is higher than the growth rates of $\operatorname{In}_{2} \mathrm{~S}_{3}$ shown in Figure 1 and those reported in the literature for this deposition temperature [9,26-28]. Optical measurements revealed an onset absorption moving to higher energies when increasing the number of $\operatorname{In}_{2} \mathrm{O}_{3}$ cycles. At the same time, the optical band gap increased from $2.2 \mathrm{eV}$ to $3.3 \mathrm{eV}$ for $\operatorname{In}_{2} \mathrm{O}_{3}$ cycle ratios in the range from 0 to $11.8 \%$. EDX analysis showed that those films have a high oxygen content. Finally, all attempts to synthesize pure $\operatorname{In}_{2} \mathrm{O}_{3}$ films from $\mathrm{In}(\mathrm{acac})_{3}$ and $\mathrm{O}_{2}$ plasma remained unsuccessful .

\section{Discussion}

It has been observed that inserting an $\mathrm{In}_{2} \mathrm{O}_{3}$ cycle during the deposition of $\mathrm{In}_{2} \mathrm{~S}_{3}$ when using $\mathrm{H}_{2} \mathrm{O}$ as oxygen precursor has no influence on the oxygen content and on the film properties. It only affects the growth rate as the thickness varies. Attempts to synthesize pure $\mathrm{In}_{2} \mathrm{O}_{3}$ thin films were also unsuccessful, which suggests a low reactivity of $\mathrm{H}_{2} \mathrm{O}$ towards $\mathrm{In}(\mathrm{acac})_{3}$. Several authors reported the difficulty to synthesize $\operatorname{In}_{2} \mathrm{O}_{3}$ by ALD using $\beta$-diketonates $\left(\operatorname{In}(\mathrm{acac})_{3}, \operatorname{In}(\right.$ hfac $=$ hexafluoropenta-

Table 2: EDX measurements data from $\ln _{2}(\mathrm{~S}, \mathrm{O})_{3}$ thin films when using $\mathrm{O}_{2}$ plasma.

\begin{tabular}{|c|c|c|c|c|c|}
\hline $\begin{array}{c}\mathrm{In}_{2} \mathrm{O}_{3} \\
(\%)\end{array}$ & $\begin{array}{c}\text { optical band gap } \\
(\mathrm{eV})\end{array}$ & $\begin{array}{c}(\mathrm{O}+\mathrm{S}) /(\mathrm{In}+\mathrm{S}+\mathrm{O}) \\
(\text { atom \%) }\end{array}$ & $\begin{array}{c}\ln /(\ln +\mathrm{S}+\mathrm{O}) \\
(\text { atom \%) }\end{array}$ & $\begin{array}{c}\mathrm{S} /(\ln +\mathrm{S}+\mathrm{O}) \\
(\text { atom \%) }\end{array}$ & $\begin{array}{c}\mathrm{O} /(\mathrm{In}+\mathrm{S}+\mathrm{O}) \\
(\text { atom \%) }\end{array}$ \\
\hline 4.80 & 2.76 & 83 & 17 & 15 & 68 \\
\hline 5.41 & 3.04 & 85 & 15 & 10 & 75 \\
\hline 6.25 & 3.10 & 85 & 15 & 11 & 74 \\
\hline 7.41 & 3.00 & 80 & 20 & 14 & 66 \\
\hline 9.09 & 3.22 & 79 & 21 & 10 & 69 \\
\hline 11.76 & 3.31 & 83 & 17 & 9 & 74 \\
\hline
\end{tabular}

Table 3: Comparison between $\ln _{2}(\mathrm{~S}, \mathrm{O})_{3}$ films, synthesized with and without $\ln (\text { acac })_{3}$ during the oxidation pulse, and $\ln { }_{2} S_{3}$.

\begin{tabular}{|c|c|c|c|c|c|}
\hline program & $E_{g}(e V)$ & growth rate ( $\AA$ /cycle $)$ & $\ln /(\ln +\mathrm{S}+\mathrm{O})($ atom \%) & $\mathrm{S} /(\mathrm{S}+\mathrm{O})($ atom \%) & $\mathrm{O} /(\mathrm{S}+\mathrm{O})($ atom \%) \\
\hline $20 \cdot\left\{\ln _{2} \mathrm{~S}_{3}\right\}+2 \cdot\left\{\ln _{2} \mathrm{O}_{3}\right\}$ & $3.2 \pm 0.1$ & $1.4 \pm 0.2$ & 21 & 13 & 87 \\
\hline $20 \cdot\left\{\ln _{2} S_{3}\right\}+2 \cdot O_{2}$ plasma & $3.3 \pm 0.1$ & $1.2 \pm 0.2$ & 17 & 15 & 85 \\
\hline $\ln _{2} \mathrm{~S}_{3}$ & $2.2 \pm 0.2$ & $0.7 \pm 0.08$ & 35 & 70 & 30 \\
\hline
\end{tabular}


dionate $)_{3}, \operatorname{In}($ thd $=2,2,6,6$-tetramethyl-3,5-heptanedioneate) and water $[20,21,25]$. In most cases, they assigned the low growth rates or the absence of grown films to the low reactivity of water toward $\beta$-diketonates.

As no pure $\mathrm{In}_{2} \mathrm{O}_{3}$ films could be grown in our case, the synthesis of mixed films by a simple addition of two layers, i.e. $\mathrm{In}_{2} \mathrm{O}_{3}+\mathrm{In}_{2} \mathrm{~S}_{3}$, is not possible. However, the deposition of ternary materials can also occur via exchange reactions. For instance, when synthesizing zinc indium sulfide (ZIS) thin films, substitution mechanisms between diethylzinc (DEZ) and $\mathrm{In}_{2} \mathrm{~S}_{3}$ could be demonstrated [11]. Similar mechanisms also occur when inserting $\mathrm{H}_{2} \mathrm{O}$ in pure $\mathrm{ZnS}$ during the growth of $\mathrm{Zn}(\mathrm{S}, \mathrm{O})$ by using ALD $[4,16]$. Such processes do not seem to occur in our case, because the $\operatorname{In}_{2}(\mathrm{~S}, \mathrm{O})_{3}$ deposition method that uses $\mathrm{H}_{2} \mathrm{O}$ remained unsuccessful. A possible thermodynamic explanation for the unfavorable deposition of $\operatorname{In}_{2}(\mathrm{~S}, \mathrm{O})_{3}$ using $\mathrm{H}_{2} \mathrm{O}$ as oxygen precursor is that the following exchange reaction is endothermic and thus unlikely to occur [31].

$$
\begin{aligned}
& \mathrm{In}_{2} \mathrm{~S}_{3}(\mathrm{~s})+3 \mathrm{H}_{2} \mathrm{O}(\mathrm{g}) \rightarrow \mathrm{In}_{2} \mathrm{O}_{3}(\mathrm{~s})+3 \mathrm{H}_{2} \mathrm{~S}(\mathrm{~g}), \\
& \Delta G=98.4 \mathrm{~kJ} / \mathrm{mol} \text { at } 200{ }^{\circ} \mathrm{C}
\end{aligned}
$$

Due to the high reactivity of radicals, PEALD generally allows the achievement of many chemical reactions that cannot occur with thermal ALD $[13,19]$. Here $\operatorname{In}_{2}(\mathrm{~S}, \mathrm{O})_{3}$ films could be grown while using $\mathrm{O}_{2}$ plasma as oxygen source. But the growth of pure $\operatorname{In}_{2} \mathrm{O}_{3}$ films remained unsuccessful. This suggests that the oxygen contained in $\operatorname{In}_{2}(\mathrm{~S}, \mathrm{O})_{3}$ films is not generated from single layers of $\operatorname{In}_{2} \mathrm{O}_{3}$ but rather by exchange reactions as described in the previous section. Indeed, the $\mathrm{O}_{2}$ plasma can directly react with the film surface and induce an exchange reaction with surface sulfur atoms. Figure 7 presents a scheme of the assumed substitution mechanism at the surface.

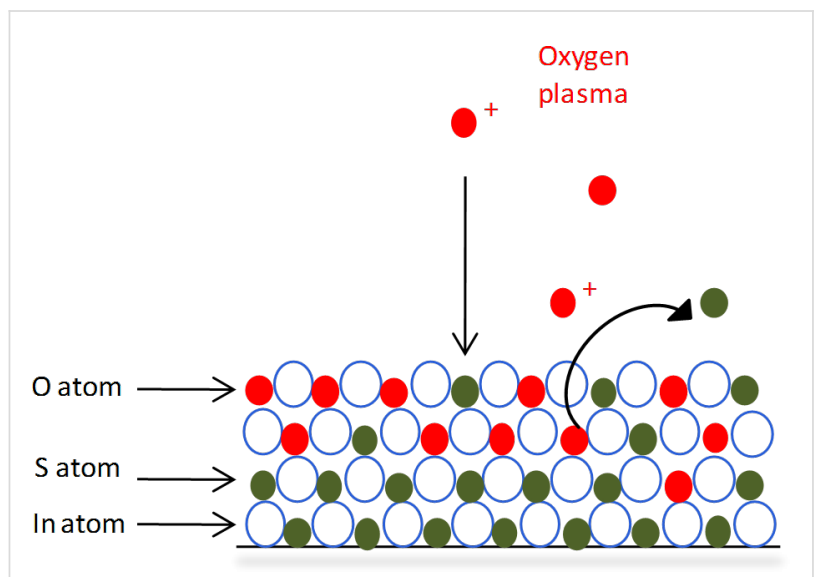

Figure 7: Surface mechanisms during the $\mathrm{O}_{2}$ plasma pulse.
The following exchange reactions can explain the substitution of $\mathrm{S}$ atoms by reactive oxygen species generated in the plasma. Indeed, their free standard enthalpies all have negative values:

$$
\begin{aligned}
& \operatorname{In}_{2} \mathrm{~S}_{3}(\mathrm{~s})+3 \mathrm{O}^{+\circ}(\mathrm{g}) \rightarrow \mathrm{In}_{2} \mathrm{O}_{3}(\mathrm{~s})+3 \mathrm{~S}^{+}(\mathrm{g}) \\
& \Delta G=-1413.3 \mathrm{~kJ} / \mathrm{mol} \text { at } 200^{\circ} \mathrm{C} \\
& \mathrm{In}_{2} \mathrm{~S}_{3}(\mathrm{~s})+3 \mathrm{O}(\mathrm{g}) \rightarrow \mathrm{In}_{2} \mathrm{O}_{3}(\mathrm{~s})+3 \mathrm{~S}(\mathrm{~g}), \\
& \Delta G=-462.3 \mathrm{~kJ} / \mathrm{mol} \text { at } 200^{\circ} \mathrm{C}
\end{aligned}
$$$$
2 \mathrm{In}_{2} \mathrm{~S}_{3}(\mathrm{~s})+3 \mathrm{O}_{2}^{+\circ}(\mathrm{g}) \rightarrow 2 \mathrm{In}_{2} \mathrm{O}_{3}(\mathrm{~s})+3 \mathrm{~S}^{+}(\mathrm{g})+3 \mathrm{~S}(\mathrm{~g}),
$$$$
\Delta G=-95.8 \mathrm{~kJ} / \mathrm{mol} \text { at } 200{ }^{\circ} \mathrm{C}
$$

Thus, when comparing these reactions with the reaction between $\mathrm{In}_{2} \mathrm{~S}_{3}$ and $\mathrm{H}_{2} \mathrm{O}$, it seems that the doping is only favorable when using $\mathrm{O}_{2}$ plasma as oxygen precursor, because these reactions are all exothermic. This thermochemical analysis and the observation that $\operatorname{In}_{2}(\mathrm{O}, \mathrm{S})_{3}$ films obtained from the two different ALD pulse programs $20 \cdot\left\{\mathrm{In}_{2} \mathrm{~S}_{3}\right\}+2 \cdot\left\{\mathrm{In}_{2} \mathrm{O}_{3}\right\}$ and $20 \cdot\left\{\mathrm{In}_{2} \mathrm{~S}_{3}\right\}+2 \cdot \mathrm{O}_{2}$ plasma have similar properties, show the critical role of activated oxygen during the deposition of $\mathrm{In}_{2}(\mathrm{~S}, \mathrm{O})_{3}$.

Commonly existing species in oxygen plasmas are atomic oxygen that is created from molecular oxygen dissociation, excited oxygen species at different electronic levels, ionized oxygen or recombined species like $\mathrm{O}_{3}$ [32,33]. Consequently, exchange reactions between adsorbed oxygen and oxygen species from the gas phase or recombination reactions have to be considered. Marinov et al. studied the interactions between a radiofrequency $\mathrm{O}_{2}$ plasma and oxide surfaces like $\mathrm{TiO}_{2}, \mathrm{SiO}_{2}$ and Pyrex [32]. They demonstrated that these materials surfaces are continuously re-structured under $\mathrm{O}_{2}$ plasma exposure because of the exchange reactions that occur between $\mathrm{O}$ atoms in the films and oxygen species of the gas phase. They also reported that reaction products undergo oxidation at the surface and assumed that two surface mechanisms could occur; $\mathrm{O}+\mathrm{O}$ $\rightarrow \mathrm{O}_{2}$ and $\mathrm{O}+\mathrm{O}_{2} \rightarrow \mathrm{O}_{3}$. Such mechanisms might also occur in our case considering the exchange reactions described in Figure 7 during the first $\mathrm{O}_{2}$ plasma pulse. Indeed, no match was found between the ratios of $\operatorname{In}_{2} \mathrm{O}_{3}$ cycles during the deposition of $\operatorname{In}_{2}(\mathrm{~S}, \mathrm{O})_{3}$ films and the oxygen content of the films determined by EDX. When the number of $\mathrm{In}_{2} \mathrm{O}_{3}$ cycles varied from $4.8 \%$ to $11.8 \%$, in the same time the oxygen content of the films varied from 68 atom \% to 75 atom \%. Oxidation mechanisms during deposition process can explain these high differences between the expected values and those measured. 
Comparing $\operatorname{In}_{2}(\mathrm{~S}, \mathrm{O})_{3}$ films synthesized with and without an $\mathrm{In}(\mathrm{acac})_{3}$ pulse before the $\mathrm{O}_{2}$ plasma pulse, no significant differences in the band gap values or the atomic ratios of the samples were observed. This confirms that the formation of an $\mathrm{In}_{2} \mathrm{O}_{3}$ single layer is not required to synthesize $\mathrm{In}_{2}(\mathrm{~S}, \mathrm{O})_{3}$ films. These results are in fair agreement with the fact that the growth of pure $\mathrm{In}_{2} \mathrm{O}_{3}$ remained unsuccessful. Thus, we can assume that only activated oxygen is involved during the deposition of $\operatorname{In}_{2}(\mathrm{~S}, \mathrm{O})_{3}$, and $\mathrm{In}_{2} \mathrm{~S}_{3}$ can be considered as an intermediate state for the formation of $\operatorname{In}_{2}(\mathrm{~S}, \mathrm{O})_{3}$.

On-going studies focus on a better understanding on the nature of the oxygen species generated by the plasma, their role in oxidizing mechanisms and the reason of the relatively low indium content. One of them could be an excessive adsorption of oxygen in the film and the formation of sulfates. Further studies, in particular by using X-ray photoelectron spectroscopy, are in progress to assess the presence or not of such groups. Experiments will also be performed to study the influence of other oxygen sources such as $\mathrm{O}_{2}$ alone and $\mathrm{O}_{3}$.

\section{Conclusion}

In this study we reported the atomic layer deposition of $\operatorname{In}_{2}(\mathrm{~S}, \mathrm{O})_{3}$ films by using $\operatorname{In}(\mathrm{acac})_{3}$ (acac $=$ acetylacetonate $)$, $\mathrm{H}_{2} \mathrm{~S}$, and either $\mathrm{H}_{2} \mathrm{O}$ or $\mathrm{O}_{2}$ plasma as oxygen sources. $\mathrm{In}_{2}(\mathrm{~S}, \mathrm{O})_{3}$ films could only be obtained with $\mathrm{O}_{2}$ plasma as oxygen source, and all attempts to synthesize $\operatorname{In}_{2} \mathrm{O}_{3}$ remained unsuccessful. Thus, synthesis of $\operatorname{In}_{2}(\mathrm{~S}, \mathrm{O})_{3}$ films is likely to occur through an exchange reaction instead of simple mixing of $\operatorname{In}_{2} \mathrm{~S}_{3}$ and $\mathrm{In}_{2} \mathrm{O}_{3}$ layers. A thermochemical analysis can explain such observations. Indeed, this reaction is endothermic for $\mathrm{H}_{2} \mathrm{O}$ and exothermic for $\mathrm{O}_{2}$ plasma.

With this new synthesis method, the optical band gap of the thin films could be tuned from $2.2 \mathrm{eV}$ to $3.3 \mathrm{eV}$ by increasing the number of $\mathrm{O}_{2}$ plasma pulses. The high oxygen contents measured in the films ( $>66$ atom \%) in comparison to the initial number of $\mathrm{In}_{2} \mathrm{O}_{3}$ pulses might be explained by the fact that oxidation mechanisms occurred on the film surfaces during the $\mathrm{O}_{2}$ plasma pulses. Due to the reactivity of the plasma, the film surfaces cannot be considered as a static system but should rather be seen as continually re-structured surfaces. In our future studies, those films will be applied as buffer layer in $\mathrm{Cu}(\mathrm{In}, \mathrm{Ga}) \mathrm{Se}_{2}$ solar cells to investigate their suitability as Cd-free buffer layer for thin film solar cells.

\section{Experimental}

$\mathrm{In}_{2} \mathrm{~S}_{3}$ and $\operatorname{In}_{2}(\mathrm{~S}, \mathrm{O})_{3}$ thin films were deposited on borosilicate glass and $\mathrm{Si}(100)$ substrates in a SUNALE R-200 ALD reactor (Picosun Oy.) with a modified $15 \mathrm{~cm} \times 15 \mathrm{~cm}$ square reaction chamber. All samples were deposited performing a total of 2000 growth cycles. The source material for indium was indium acetylacetonate $\left(\mathrm{In}\left(\mathrm{CH}_{3} \mathrm{COCHCOCH}_{3}\right)_{3}\right), \operatorname{In}(\mathrm{acac})_{3},(98 \%$, Strem Chemicals). Hydrogen sulfide, $\mathrm{H}_{2} \mathrm{~S}$ (99.5\%, Messer) was used as the sulfur source. Deionized Millipore vapor water and $\mathrm{O}_{2}$, (99.9995\%, Messer) were used as oxygen source. $\mathrm{O}_{2}$ was introduced in a remote RF plasma generator with Argon (99.9997\%, Messer) as carrier gas, and the plasma power was kept at $2600 \mathrm{~W}$. All sources were kept at room temperature while $\operatorname{In}(\mathrm{acac})_{3}$ was heated to $200{ }^{\circ} \mathrm{C}$. The carrying and purge gas was nitrogen with a purity of $99.9999 \%$ (Messer). The pressure in the reaction chamber was kept in the range from 1 to 4 mbar.

The thickness of the films was measured using a VEECO DEKTAK 6M profilometer on glass substrates. Thicknesses were determined after creating steps in the films, by masking film parts with chemically resistant tape and dipping the film in nitric acid (45\% in water) at room temperature for $60 \mathrm{~s}$. The uncertainty given for the thickness is the standard deviation of six measurements taking into account the uncertainty of the profilometer, the sharpness of steps, the film roughness, and the film inhomogeneity. Transmittance and reflectance spectra were obtained by using a PerkinElmer lambda 900 Spectrophotometer with a PELA-1000 integrating sphere. All optical measurements were performed on borosilicate glass substrates. $\mathrm{X}$-Ray diffraction (XRD) studies were performed under grazing incidence X-ray diffraction conditions with a PANalytical Empyrean diffractometer while using $\mathrm{Cu} \mathrm{K} \alpha$ radiation. X-Ray reflectometry analyses were also performed to confirm thickness measurements. Thin film compositions were obtained by using a Magellan 400L scanning electron microscope provided by FEI. It is equipped with an energy dispersive X-ray spectroscopy detector INCASynergy 350. All EDX measurements were carried out on $\mathrm{Si}(100)$ substrates and the values reported are atomic percentages (atom \%).

\section{Acknowledgements}

This work is supported by Ministry of Higher Education and Research via Pierre and Marie Curie University (UPMC, ED390) and EDF. Energy Dispersive X-Ray Specroscopy measurements were performed by S.Borenztajn (CNRS) and Laboratoire de Photonique et Nanostructures (CNRS).

\section{References}

1. Jackson, P.; Hariskos, D.; Lotter, E.; Paetel, S.; Wuerz, R.; Menner, R.; Wischmann, W.; Powalla, M. Prog. Photovoltaics 2011, 19, 894-897. doi:10.1002/pip.1078

2. Empa - CIGS. http://www.empa.ch/plugin/template/empa/*/79143 (accessed July 31, 2013).

3. Çetinörgü, E.; Gümüş, C.; Esen, R. Thin Solid Films 2006, 515, 1688-1693. doi:10.1016/j.tsf.2006.06.004 
4. Nakamura, M.; Kouji, Y.; Chiba, Y.; Hakuma, H.; Kobayashi, T.; Nakada, T. Achievement of $19.7 \%$ efficiency with a small-sized $\mathrm{Cu}(\mathrm{InGa})(\mathrm{SeS}) 2$ solar cells prepared by sulfurization after selenizaion process with Zn-based buffer. 38th IEEE Photovoltaic Specialists Conference, June 3-8, 2012; Austin, TX.

5. Hariskos, D.; Menner, R.; Jackson, P.; Paetel, S.; Witte, W.; Wischmann, W.; Powalla, M.; Bürkert, L.; Kolb, T.; Oertel, M.; Dimmler, B.; Fuchs, B. Prog. Photovoltaics 2012, 20, 534-542. doi:10.1002/pip.1244

6. Hariskos, D.; Ruckh, M.; Rühle, U.; Walter, T.; Schock, H. W.; Hedström, J.; Stolt, L. Sol. Energy Mater. Sol. Cells 1996, 41-42, 345-353. doi:10.1016/0927-0248(96)80009-2

7. Zimmermann, U.; Ruth, M.; Edoff, M. In 21st European Photovoltaic Solar Energy Conference: Proceedings of the international conference held in Dresden, Dresden, Germany, Sept 4-8, 2006; pp 1831-1834.

8. Platzer-Björkman, C.; Hultqvist, A.; Pettersson, J.; Törndahl, T. Proc. SPIE 2010, 7603, 76030F. doi:10.1117/12.846017

9. Naghavi, N.; Spiering, S.; Powalla, M.; Cavana, B.; Lincot, D. Prog. Photovoltaics 2003, 11, 437-443. doi:10.1002/pip.508

10. Lindahl, J.; Zimmermann, U.; Szaniawski, P.; Torndahl, T.; Hultqvist, A.; Salome, P.; Platzer-Bjorkman, C.; Edoff, M. IEEE J. Photovoltaics 2013, 3, 1100-1105. doi:10.1109/JPHOTOV.2013.2256232

11. Genevée, P.; Donsanti, F.; Renou, G.; Lincot, D. J. Phys. Chem. C 2011, 115, 17197-17205. doi:10.1021/jp203604j

12. Genevée, P.; Donsanti, F.; Renou, G.; Lincot, D. Atomic Layer Deposition of ZnInxSy Buffer Layers For Copper Indium Gallium Diselenide Thin Film Solar Cells. In 26th European Photovoltaic Solar Energy Conference and Exhibition: EU PVSEC Proceedings, Hamburg, Germany, Sept 5-8, 2011; pp 2428-2431. doi:10.4229/26thEUPVSEC2011-3C0.4.4

13. Miikkulainen, V.; Leskela, M.; Ritala, M.; Puurunen, R. L. J. Appl. Phys. 2013, 113, 021301. doi:10.1063/1.4757907

14. van Delft, J. A.; Garcia-Alonso, D.; Kessels, W. M. M. Semicond. Sci. Technol. 2012, 27, 074002. doi:10.1088/0268-1242/27/7/074002

15. Bakke, J. R.; Pickrahn, K. L.; Brennan, T. P.; Bent, S. F. Nanoscale 2011, 3, 3482-3508. doi:10.1039/c1nr10349k

16. Platzer-Björkman, C.; Törndahl, T.; Abou-Ras, D.; Malmström, J.; Kessler, J.; Stolt, L. J. Appl. Phys. 2006, 100, 044506. doi:10.1063/1.2222067

17. Barreau, N.; Marsillac, S.; Albertini, D.; Bernede, J. C. Thin Solid Films 2002, 403-404, 331-334. doi:10.1016/S0040-6090(01)01512-7

18. Maha, M. H. Z.; Bagheri-Mohagheghi, M.-M.; Azimi-Juybari, H.; Shokooh-Saremi, M. Phys. Scr. 2012, 86, 055701. doi:10.1088/0031-8949/86/05/055701

19. Kim, H. Thin Solid Films 2011, 519, 6639-6644. doi:10.1016/j.tsf.2011.01.404

20. Asikainen, T.; Ritala, M.; Leskelä, M. J. Electrochem. Soc. 1994, 141, 3210-3213. doi:10.1149/1.2059303

21. Elam, J. W.; Martinson, A. B. F.; Pellin, M. J.; Hupp, J. T. Chem. Mater. 2006, 18, 3571-3578. doi:10.1021/cm060754y

22. Elam, J. W.; Libera, J. A.; Hryn, J. N. ECS Trans. 2011, 41, 147-155. doi:10.1149/1.3633663

23. Lee, D.-J.; Kwon, J.-Y.; Lee, J. I.; Kim, K.-B. J. Phys. Chem. C 2011, 115, 15384-15389. doi:10.1021/jp2024389

24. Nilsen, O.; Balasundaraprabhu, R.; Monakhov, E. V.; Muthukumarasamy, N.; Fjellvåg, H.; Svensson, B. G. Thin Solid Films 2009, 517, 6320-6322. doi:10.1016/j.tsf.2009.02.059
25. Asikainen, T.; Ritala, M.; Leskelä, M. Appl. Surf. Sci. 1994, 82-83, 122-125. doi:10.1016/0169-4332(94)90206-2

26. Yousfi, E. B.; Weinberger, B.; Donsanti, F.; Cowache, P.; Lincot, D. Thin Solid Films 2001, 387, 29-32. doi:10.1016/S0040-6090(00)01838-1

27. Sterner, J.; Malmström, J.; Stolt, L. Prog. Photovoltaics 2005, 13, 179-193. doi:10.1002/pip.595

28. Sarkar, S. K.; Kim, J. Y.; Goldstein, D. N.; Neale, N. R.; Zhu, K.; Elliott, C. M.; Frank, A. J.; George, S. M. J. Phys. Chem. C 2010, 114, 8032-8039. doi:10.1021/jp9086943

29. Hishikawa, Y.; Nakamura, N.; Tsuda, S.; Nakano, S.; Kishi, Y.; Kuwano, Y. Jpn. J. Appl. Phys. 1991, 30, 1008-1014. doi:10.1143/JJAP.30.1008

30. Liu, D.; Lei, W. W.; Zou, B.; Yu, S. D.; Hao, J.; Wang, K.; Liu, B. B.; Cui, Q. L.; Zou, G. T. J. Appl. Phys. 2008, 104, 083506. doi:10.1063/1.2999369

31. HSC Chemistry; Chemistry Software Ltd, 2013.

32. Marinov, D. Adsorption réactive des molécules et radicaux sur des surfaces sous exposition plasma. Ph.D. Thesis, Ecole Polytechnique X, Palaiseau, France, 2012.

33. Lopaev, D. V.; Malykhin, E. M.; Zyryanov, S. M. J. Phys. D: Appl. Phys. 2011, 44, 015202. doi:10.1088/0022-3727/44/1/015202

\section{License and Terms}

This is an Open Access article under the terms of the Creative Commons Attribution License (http://creativecommons.org/licenses/by/2.0), which permits unrestricted use, distribution, and reproduction in any medium, provided the original work is properly cited.

The license is subject to the Beilstein Journal of

Nanotechnology terms and conditions:

(http://www.beilstein-journals.org/bjnano)

The definitive version of this article is the electronic one which can be found at: doi:10.3762/bjnano.4.85 